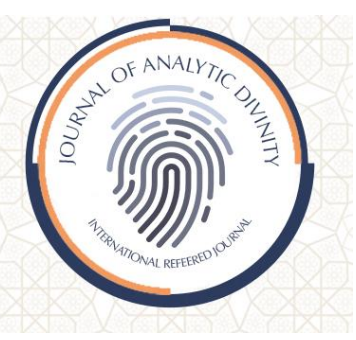

\author{
Journal of Analytic Divinity \\ International Refereed Journal \\ E-ISSN: 2602-3792 \\ Haziran/ June 2021/5 (2): ss-pp 212-235
}

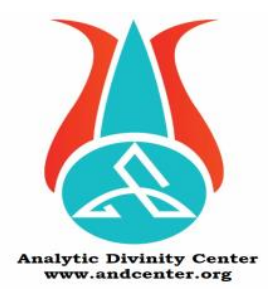

\title{
İlahi Dinlerde Oruç: Kaynağı, Amacı ve Uygulanışı Bakımından Karşılaştırmalı Bir İnceleme
}

Fasting in the Divine Religions: A Comparative Study in Terms of Origin, Purpose and Practice

\section{Rahim Ay}

Dr. Öğr. Üyesi, AYBÜ, İslami İlimler Fakültesi, Felsefe ve Din Bilimleri Bölümü Asst. Prof., AYBU, Faculty of Islamic Studies, Dept. of Philosophy and Religious Studies

\author{
Ankara/Türkiye \\ Ankara/Türkiye,rahimay@ybu.edu.tr \\ https:/ / orcid.org/0000-0002-3486-1031
}

\section{Makale Bilgisi | Article Information}

Makale Türü / Article Type: Derleme Makalesi / Review Article

Geliş Tarihi / Date Received: 1 Mayıs/ May 2021

Kabul Tarihi / Date Accepted: 10 Haziran/ June 2021

Yayın Tarihi / Date Published: 15 Haziran/15 June 2021

Yayın Sezonu / Pub Date Season: Yaz- Haziran/ Summer-June

DOI: $10.46595 /$ jad. 931235

Cite as / Atıf: Ay, Rahim. “ilahi Dinlerde Oruç: Kaynağı, Amacı ve Uygulanışı Bakımından Karşılaştırmalı Bir İnceleme", Journal of Analytic Divinity, 5/2 (June 2021): 212-235.

İntihal: Bu makale, iThenticate yazılımınca taranmıştır. İntihal tespit edilmemiştir. Plagiarism: This article has been scanned by iThenticate. No plagiarism detected. Web: http://dergipark.org.tr/jad | e-mail to: editorjand@gmail.com

Copyright $\odot$ Published by Özcan Güngör, Ankara Yıldırım Beyazıt Üniversitesi, İslami İlimler Fakültesi / Ankara Yıldırım Beyazıt University, Faculty of Islamic Studies, Ankara-Turkey. Bütün hakları saklıdır. / All right reserved. 
Ay, Rahim. İlahi Dinlerde Oruç: Kaynağı, Amacı ve Uygulanışı Bakımından Karşılaştırmalı Bir İnceleme

\title{
Öz
}

Bu makalenin konusu oruç ibadeti, amacı ise ilahi dinlerde orucun kaynak, amaç ve uygulanış biçimleri bakımından incelenerek benzer ve farklı yönlerin tespit edilmesidir. Oruç sadece Yahudilik, Hıristiyanlık ve İslam gibi ilahi dinlerde değil, kurumsallaşmış bütün dünya dinlerinde mevcuttur. Orucun diğer bazı dini ritüellerden farkı vardır. Dinlerde oruç hem insanın günahlardan arınması ve erdemli bir ahlaka kavuşması hem de din mensuplarının ortak acı ve sevinçlerinin hatırlanması ve bundan ders çıkarılması için önem arz etmektedir. Yahudilikte orucun daha çok sosyal ve tarihi yönü öne çıkmaktadır. Hıristiyanlıkta riyazet ve kendini kötülüklerden sakınma boyutu baskındır. Hıristiyanlıkta aynı zamanda susma da orucun bir şekli olarak işlevseldir. İslam'da oruç kişinin kötülüklerden sakınmasını sağlama amacı taşıdığı gibi sosyal hayatta empati yapmaya da yardımcı olur. Kur'an, orucun önceki toplumlarda da mevcut olduğunu belirterek ilahi dinlerdeki ortak amaçlı oruca vurgu yapmaktadır. Bu çalışmada orucun üç dindeki amacı, kaynakları, uygulama şekilleri ve çeşitleri ele alınmıştır. İslam'da orucun uygulanışına dair birçok kural vardır. Ancak biz konu kapsam ve sınırlılığımız gereği orucun fıkhi yönünün ayrıntılarına girmedik.

Anahtar Kelimeler: Dinler Tarihi, Yahudilik, Hıristiyanlık, İslam, Oruç.

\begin{abstract}
The subject of this article is worship of fasting, and its aim is to identify similarities and differences among the divine religions by examining the sources, purposes, and forms of fasting. Fasting exists not only in divine religions such as Judaism, Christianity, and Islam, but in all institutionalized world religions. Fasting is different from some other religious rituals. In religions, fasting is important both for the purification of people from sins and for attaining a virtuous morality, as well as for remembering the common pains and joys of religious members and learning lessons from them. In Judaism, fasting has a more social and historical aspect. In Christianity, asceticism and the avoidance of evil are dominant. Moreover, another functional form of fasting in Christianity is silence. In Islam, fasting not only aims to avoid evil, but also helps to empathize in social life. The Qur'an emphasizes the common purpose of fasting in the divine religions, stating that fasting also existed in previous societies. In this study, the purpose, sources, application forms and types of fasting in three religions are discussed. There are many rules in Islam regarding the application of fasting. However, due to the limited scope of the subject, the details of the fiqh aspect of fasting were not discussed.
\end{abstract}

Keywords: History of Religions, Judaism, Christianity, Islam, Fasting. 


\section{Giriş}

Bu makale çalışmasında ilahi dinlerde orucu kaynak, amaç ve uygulanışı bakımından karşılaştırmalı olarak inceleyeceğiz. Amacımız üç ilahi dinde tutulan oruçların çeşitli boyutlarıyla benzerlik ve farklılıklarını tespit etmektir. İslam'daki oruç ibadetiyle ilgili özellikle fıkhi boyutu bakımından yapılmış çok sayıda araştırma vardır. Yahudilik ve Hıristiyanlık hakkında da bağımsız olarak yapılmış birçok araştırma mevcuttur. Türkçe araştırmalar içinde ilahi dinleri benzerlik ve farklılıklarıyla incelemeyi amaçlayan iki önemli çalışma olarak Hasan Büyükkaya' nın "İlahi Dinlerde Oruç" adlı yüksek lisans tezini ve Recep Demir'in “Diğer İnanç Sistemlerinde ve İslam'da Oruç (Karşılaştırmalı Bir Analiz)" adlı makale çalışmasını örnek verebiliriz. ${ }^{1}$

Çalışmada önce her bir ilahi dinde oruç ibadeti anlam, amaç, kaynak, uygulanış ve çeşitleri bakımından incelenecek, sonra üç din yine bu açılardan karşılaştırılarak değerlendirilecektir. Çalışmada orucun fıkhi yönüyle ilgili ayrıntılara girilmeyecek, sadece dinler tarihi araştırmacılığı açısından ele alınacaktır. Özellikle İslam’da orucun edasıyla ilgili geniş fıkhi şartlar, kurallar ve hükümler gündeme getirilmeyecektir. Sadece mukayeseye imkân verecek hususlar üzerinde yoğunlaşılacaktır.

\section{Yahudilikte Oruç}

Tam veya kısmî perhiz yapma, yeme, içme ve cinsel ilişkiden uzak durma olarak tanımlanan oruç, bütün dünya dinlerinde görülen evrensel bir fenomendir. Yahudilikte orucu ifade eden "Taanit" kelimesi "yas, nefse eza etmek, pişmanlık ve imana dönüş" manasına gelmektedir. ${ }^{2}$ Yahudilikte orucun tövbe ve kefaret boyutu ön plandadır. Oruç günahlardan arınma isteğinin yanı sıra tarihte yaşanmış üzücü ve sevindirici hadislerin anılması amacıyla da tutulmaktadır. Kefaret gerektiren kötü fiili bizzat kişinin işlemiş olması şart değildir; soyunun ailesinin veya milletinden bir ferdin işlemiş olması da kefaret için yeterlidir. Oruç aynı zamanda Yahudilikte bir matem belirtisidir. Ayrıca Kral Davud'un yaptığı gibi duaya hazırlık ritüeli olarak da görülmüştür.

\subsection{Yahudilikte Orucun Kaynağı, Amacı ve Uygulanışı}

Yahudilikte oruç ibadeti, bir kefaret, pişmanlık ifadesi, teslimiyet ve dua işlevi görmektedir. ${ }^{3}$ Tevrat'ta oruçtan nefsi kırma, cefa çekme, Tanrı'ya yakınlaşma vesilesi olarak bahsedilmektedir. ${ }^{4}$ Tevrat' ta emredilen tek oruç Yom Kippur orucudur. Kaynakların Yom Kippur dışında bahsettiği bir diğer oruç "Dokuzuncu Av" orucudur. ${ }^{5}$ Yeşaya 58/38 'de ifade edildiğine göre, nefis ancak oruçla alçaltılabilir ve kişi hakiki manada yalnızca

\footnotetext{
1 Hasan Büyükkaya, İlahi Dinlerde Oruç (Kastamonu: Kastamonu Üniversitesi Sosyal Bilimler Enstitüsü, Yüksek Lisans Tezi, 2018); Recep Demir, "Diğer İnanç Sistemlerinde ve İslam’da Oruç (Karşılaştırmalı Bir Analiz)”, Uluslararası Sosyal Araştırmalar Dergisi $9 / 42$ (2016), 1785-1799.

2 Abdurrahman Küçük - G. Tümer - M. A. Küçük, Dinler Tarihi (Ankara: Berikan Yayınevi, 2010), 330.

3 "Fasting and Fast Days", Jewish Virtual Library, 2011, https://www.jewishvirtuallibrary.org/fasting-andfast-days-2 10.05.2021.

${ }^{4}$ Mezmurlar, 35:13, 69/10, 109:24; Daniel, 9:3

5 Jacob Milgrom, "Forgiveness, in the Bible", Encyclopaedia Judaica Second Edition, ed. in Chief, F. Skolnik (Detroit: Thomson\& Gale, 2007), 7/127.
} 
orucunu kötülüklerden uzaklaşma, tevazu, mazlumlara ve düşkünlere yardım etme gibi iyiliklerle desteklediği takdirde oruç tutmuş olur.

Yahudilikte oruç çoğunlukla, kişinin kasıtlı veya kasıtsız olarak yaptığı hata ve kötü eylemlerin kefareti yahut işlediği hatadan dolayı duyduğu pişmanlığın tezahürü olarak değerlendirilmektedir. Orucu gerektiren eylem, kişinin kendi yaptığı kötü fiil olabileceği gibi, ailesi, soyu veya milletinden bir kimsenin yaptığ1 kötü fiil veya kusur da olabilir. ${ }^{6}$ Samiriye kralı Ahab' in emrine karşı gelmiş olan Yizrelli Nabot'un kavmine, bu yöneticinin işlediği fiile kefaret olarak tutmaları emredilen oruç böyledir.7 Ayrıca Komutan Saul'ün, Yonatan adlı askerinin nöbet yerini terk etmesi üzerine komutasındaki bütün askerlere, bu kusurdan dolayı bir gün oruç tutmalarını emretmesi de bu kategoriye girmektedir. ${ }^{8}$

Oruç hem cemaat halinde hem de şahsi olarak tutulabilmektedir. I. Mabed döneminde başvurulduğu gibi, milli bir liderin ölümü anısına bir günden yedi güne kadar sürebilen uygulamalar söz konusudur. ${ }^{9}$ II. Mabed döneminde oruç, arınmak ve Tanrı'ya daha yakın olmak amacıyla bir züht şekli olarak görülmüştür. I. Mabed günlerinde ihtiyari bir olgu olan oruç, büyük sürgünden sonra düzenli olarak yapılan bir ibadete dönüşmüş̧ür. ${ }^{10}$ Günümüzde oruç, genel olarak Mistikler, Kabalistler ve Hasidilerin riayet ettikleri ve düzenli olarak yerine getirdikleri bir ibadettir. ${ }^{11}$

Yahudilikte oruç, Hz. Musa' dan beri var olmakla birlikte orucun sayısı ve uygulanış biçimleri tarihi süreçte bazı değişikliklere uğramıştır. Tevrat'ta anlatıldığına göre Hz. Musa, Sina Dağı'nda vahiy alırken "kırk gün kırk gece" oruç tutmuştur.12 Tevrat, 40 günlük orucun dışında Yahudilerin sıkıntılı dönemlerde Allah'ın rahmet ve mağfiretini kazanmak için oruç tuttuklarından bahsetmektedir. ${ }^{13}$ Yaşanmış acı olaylar, sonraki dönemlerde Hahamlar tarafından oruç günü olarak belirlenmiştir. Bütün bunlar Yom Kippur dışındaki oruçların Hahamlarca belirlendiğini göstermektedir. ${ }^{14}$

Talmud'da hahamların oruç ihdas etme yetkisine sahip olduklarından bahsedilmektedir. Hahamlar bu yetkiye dayanarak genel bir oruç günü ilan edilmesine dair kanun çıkarmışlar ve sabit oruç günlerinde uyulacak kuralları belirlemişlerdir. ${ }^{15}$ Yaşanan acı olayların hatırasını canlı tutmak için sonraki dönemlerde 25 günlük bir oruç listesi daha oluşturulmuştur. Fakat genel kabul görmeyen bu oruçlar yalnızca Hahamlar ve belirli gruplar tarafından tutulmuştur. Talmud'daki bu yetki kullanılarak değişik bölgelerdeki

\footnotetext{
${ }^{6}$ E. Arıklı (ed.), Dinler Tarihi Ansiklopedisi (İstanbul: Gelişim Basım ve Yayım A.Ş., ty.),422-423

7 I. Krallar 21/1-10.

8 I. Samuel 14/16-24. bk. Ali İhsan Yitik, “İzmirli İsmail Hakkı ve Diğer Dinlerde Oruç”, İzmirli İsmail Hakkı Sempozyumu 24-25 Kasım 1995 (Ankara: TDV Yayınları, 1995), 223.

9 Yeremya 36/9; I. Samuel 31/13.

10 Mosha David Herr, "Fasting and Fast Days", Encyclopedia Judaica Second Edition, ed. F. Skolnik (Detroit: Thomson - Gale, 2007), 6/721.

${ }^{11}$ Herr, "Fasting and Fast Days", 6/722.

12 Çıkış 34:28.

13 Hakimler 20:26; Samuel 7:6.

14 "Fasting and Fast Days," Jewish Virtual Library, http://www.jewishencyclopedia.com/articles/6033fasting-and-fast-days 10.05.2021.

15 Yusuf Besalel, Yahudilik Ansiklopedisi (İstanbul: Gözlem Gazetecilik Basın ve Yayın A.Ş., 2001), 3/691.
} 
Yahudi cemaatleri ya kendilerine özgü yeni oruç günleri belirlemişler ya da mevcut oruç günlerini yeni bir gerekçeye bağlayarak devam ettirmişlerdir. ${ }^{16}$

Orucun nasıl tutulacağı, oruç tutarken riayet edilmesi gereken şartlar konusunda Yahudi Kutsal Kitabı'nda şöyle denmektedir: "Orucunuz kavgayla, çekişmeyle, şiddetli yumruklaşmayla bitiyor. Bugünkü gibi oruç tu tmakla sesinizi yükseklere duyuramazsinız. İstediğim oruç bu mu sanıyorsunuz? Insanın isteklerini denetlemesi gereken gün böyle mi olmah? Kamış gibi baş eğip çul ve kül üzerine mi oturmalı? Siz buna mı oruç, Rabbi hoşnut eden gün diyorsunuz? Benim istediğim oruç, haksız yere zincire, boyunduruğa vurulanları salıvermek, ezilenleri özgürlüğe kavuşturmak, her türlü boyunduruğu kırmak değil mi? Yiyeceğinizi açla paylaşmak değil mi? Barınaksız yoksulları evinize alır, çılak gördüğünüzü giydirir, yakınlarınızdan yardımınızı esirgemezseniz, ışı̆̆ınız tan gibi ă̆aracak, çabucak şifa bulacaksınız. Doğruluğunuz önünüzden gidecek, Rabbin yüceliği artçınız olacak."17

\subsection{Yahudilikte Oruç Çeşitleri}

Yahudilikte en önemli oruç Yom Kippur orucu olmakla birlikte mecburi oruçlar kapsamında altı oruç yer almaktadır. Hususi oruçlar daha çoktur, ancak biz en çok bilinenleri dokuz madde halinde ele alacağız.

\subsubsection{Mecburi Oruçlar}

Yahudilikteki mecburi oruçlar, Yom Kippur Orucu, Dokuz Av Orucu, Dördüncü Ay Orucu, Yedinci Ay Orucu, Onuncu Ay Orucu, Ester Orucudur.

\section{a) Yom Kippur Orucu}

Kefaret günü anlamına gelen Yom Kippur, İbranicede "Yom ha Kippurim" diye ifade edilir. Yahudiler nazarında yılın en kutsal günü Yom Kippur'dur. Adını Tevrat'tan alan Yom Kippur, "Yom A-Kadoş" (Kutsal Gün)", "Şabat Şabaton" (Şabatların Şabatı) gibi isimlerle de anılmaktadır. ${ }^{18}$ Yom Kippur, Şabat'la çakıştığında ertelenmeyen yegâne oruçtur. Bu günün önemi, Tevrat'taki “Tanrı'nın önünde pişmanlığını ifade etme" ve "ruhunu terbiye etme" emirlerinden kaynaklanmaktadır. ${ }^{19}$ Ruh terbiyesi, bedenin yeme ve içmeden alıkonması, günahlardan duyulan pişmanlığın itiraf edilmesi ve Tanrı'nın mağfiretini kazanmak için tövbe edilmesi yoluyla mümkündür. ${ }^{20}$ Yom Kippur, tövbe ve kefaret zamanıdır. Yahudi takviminin yedinci ayı olan Tişri (Eylül-Ekim) ayının onuncu gününe tekabül eder. $\mathrm{Bu}$ günde tüm insanların Tanrı önünde yargılanacağına inanılmaktadır.

Yom Kippur, İbrani takviminde Roş ha-Şana'nın ilk gününden itibaren devam eden on günlük tövbe zamanı sonundaki en kutsal gün olup kefaret günü anlamına gelmektedir. ${ }^{21}$

\footnotetext{
${ }^{16}$ Küçük - Tümer - Küçük, Dinler Tarihi, 329-330; Osman Cilac1, İlahi Dinlerde Oruç, Hac ve Kurban (İzmir: Akyol Neşriyat ve Matbaacılık, 1980), 90-100.

17 Yeşaya 58:4-8.

18 Levililer 23:27, 32.

19 Levililer 16:29-31.

20 Besalel, Yahudilik Ansiklopedisi, 793.

${ }^{21}$ Mehmet Katar, “Dinlerde Kefaret Anlayışı”, Dini Araştırmalar Dergisi 1/1 (1998), 45.
} 
Ay, Rahim. İlahi Dinlerde Oruç: Kaynağı, Amacı ve Uygulanışı Bakımından Karşılaştırmalı Bir İnceleme

Yom Kippur orucu Tevrat'ta şöyle zikredilmektedir:

"Ve sizin için ebedî bir kanun olacak; yedinci ayda, ayın onuncu gününde, canlarınızı alçaltacaksınız. Yerli olsun ve aranızda misafir bulunan garip olsun, hiçbir iş yapmayacaksınız. Çünkü o günde, sizi temizlemek üzere sizin için kefaret edilecektir. Rabbin önünde bütün suçlannızdan temizleneceksiniz."22

"Rab Musa'ya söyleyip dedi: Bu yedinci gün, ayın tam onuncu günü, kefaret günüdür. Bizim için mukaddes toplantı olacaktır ve canlarınızı alçaltacaksınız ve Rabb'e ateşle yapılan takdime arz edeceksiniz. O günde hiçbir iş yapmayacaksınız. Çünkü sizin için Allah'ınız Rabb'ın önünde kefaret etmek üzere kefaret günüdür." 23

Kur'an'daki şu ayetin Tevrat'ta bahsedilen hususa işaret ettiği anlaşılmaktadır: "Ey kavmim! Şüphesiz siz, buză̆ıyı (tanr) edinmekle kendinize kötülük ettiniz. Onun için Yaratıcınıza tövbe edin de nefislerinizi (kötü duygularınız) öldürün. Öyle yapmanız Yaratıcınızın katında sizin için daha iyidir. Böylece Allah tövbenizi kabul etmiş olur. Çünkü acıyıp tövbeleri kabul eden ancak O'dur." 24

Yom Kippur gününün Arife akşamından sonraki günün akşamına kadar yirmi beş saat oruç tutulmaktadır. Yom Kippur gününde yapılan ibadetler sayesinde o yılın güzel geçeceğine inanılmaktadır. Oruç, güneşin batması ile başlar, ertesi akşam gökyüzünde yıldızların görünmesiyle son bulur. Yom Kippur sürecinde uygulanan bazı ritüeller vardır. Yom Kippur'da ibadet dışında dünyevi işler yasaklanmış olsa da günümüzde bazı Yahudiler öğleye kadar çalışmaktadırlar. ${ }^{25}$

Yahudi inancına göre, insanın Roş ha-Şana'da planlanan bir yıllık kaderi, Yom Kippur'da yapılan ibadet ve tövbenin niteliğine göre onaylanarak son şekli verilir. Bu önemli günde dargınların barışması istenir. Tanrı' dan bağışlanma dilenen bu günde oruç tutmanın yanında zamanın büyük bir kısmı sinagoglarda ibadet ederek geçirilir. ${ }^{26}$

Sağlıklı olan her Yahudi, Yom Kippur orucunu tutmakla mükelleftir. Oruca başlama yaşı erkelerde 13, kızlarda 12'dir. Hastalar doktor veya hahamın tavsiyesi üzerine ilaç alabilir ve biraz yiyecek yiyebilirler. Daha zor bir durumda olanlar ise hiç oruç tutmazlar. Sağlı̆̆ı el veren hamile kadın ile doğumun üzerinden sekiz gün geçmiş olan loğusa kadının oruç tutması gerekir. Boy abdesti almak şeklinde yıkanmak yasak olsa da sabah kalkınca ellerin ve gözlerin hafifçe yıkanmasında mahzur görülmez. Roş ha-Şana ile Yom Kippur arasında hiçbir iş başlatılmaz, düğün yapılmaz, mahkemelerde dava açılmaz. ${ }^{27}$

Yom Kippur orucunun, Hz. Musa'nın Tûr dağında bulunduğu sırada Yahudilerin altın bir buzağıya tapmaları sebebiyle pişmanlık duyup temize çıkmak amacıyla tutulduğu belirtilmektedir. Bu nedenle Yom Kippur, pişmanlık, yakarış, dua, kendini hesaba çekme,

\footnotetext{
22 Levîliler 16:29-31.

${ }^{23}$ Levîliler 2:26-29.

24 Bakara 2/54; Bakara 2/51-52; A'raf 7/148-149.

${ }^{25}$ S. E. Karesh - M. M. Hurvitz, Encyclopedia of Judaism (New York: Facts on File Inc., 2005), 567; Abid Ahmad,

"Fasting in Religions", Subscription Review of Religions 97/3 (March 2002), 33.

${ }^{26}$ Suzan Alalu vd., Yahudilikte Kavram ve Değerler, Dinsel Bayramlar, Dinsel Kavramlar, Dinsel Gereçler (İstanbul: Gözlem Gazetecilik Basın ve Yayın, 2001), 45; Küçük vd., Dinler Tarihi, 323-324.

27 Besalel, Yahudilik Ansiklopedisi, 793; Alalu vd., Yahudilikte Kavram ve Değerler, 47.
} 
temize çıkma ve Teşuva'ya ulaşma günüdür. Günün belirli vakitlerinde belirli dualar okunur. ${ }^{28}$

\section{b) Dördüncü Ay Orucu (17 Tamuz)}

"Shiuah Asar be Tamuz" diye adlandırılan bu oruç, ay takvimine göre 17 Temmuz' da tutulur. Dördüncü Ay Orucu, Kutsal Kitap'ta şöyle anılmaktadır: "Her şeye egemen Rab diyor $k i$, dördüncü, beşinci, yedinci ve onuncu ayların oruçları Yahuda halkı için sevinç, coşku dolu mutlu bayramlar olacak. Bu nedenle gerçeği ve esenliği sevin."29 Bu oruç, Mabed döneminde Kudüs'ün Babil hâkimiyetine girerek, Kudüs kalelerinin düşmesi anısına tutulmaktadır. ${ }^{30} \mathrm{Bu}$ hadiseye "Orşelim Olayı" da denilmektedir. 17 Temmuz, Yahudi takviminde karanlık bir dönemin başlangıcı sayılır. Bu zaman dilimi "üç hafta" diye adlandırılır. Bu süre içinde neşeli etkinlikler yapılmaz, müzik dinlenmez, sinema ve konsere gidilmez, denize girilmez. Son dokuz gün içinde yasaklar daha da ağırlaşır. ${ }^{31}$

\section{c) Dokuz Av/Ab Orucu}

Yom Kippur'dan sonraki en önemli oruçtur. Birinci ve İkinci Mabedin yıkılışı anısına tutulur. Dokuzuncu günde Yahudilere, Birinci Mabedin Buhtunnasır (M.Ö. 586) ve İkinci Mabedin Romalılar tarafından yıkılışının yıldönümü hatırlatılır. Yahudiliğin ay takvimine göre, $\mathrm{Ab}$ ayının (Temmuz-Ağustos) dokuzuncu gününde tutulur. Diğer adı, "Tishah be $A v$ "dır. Ab orucu, bir matem orucu olup kutsal metinde "Beşinci ay orucu" şeklinde geçmektedir. ${ }^{32} \mathrm{Bu}$, Yahudi ay takvimine göre Tişri ayının birinci günü olan yılbaşının, Birinci Babil Sürgününden sonra geçici olarak 1 Nisan şeklinde değiştirilmiş olmasından ileri gelmektedir.

Dokuz Av orucu, Yahudi tarihinde yaşanan diğer felâketler anısına da tutulur. Bir cemaat orucu olduğu için bugün de Yom Kippur kuralları geçerlidir. Dokuz Av gününde Sinagog ve evlerde matem havası hâkimdir. Bu güne özgü dualar vardır. Eyüp Kitabından ve Yeremya'dan ağıtlar okunur. ${ }^{33}$ Geleneğe bağlı Yahudiler oruç tutmaya üç hafta öncesinden başlar. Şenlik yapılmaz, süs bulundurulmaz ve bu sürede evlenmek yasaktır. Bazı Yahudiler 17 Temmuz ile 9 Ağustos arasındaki üç haftalık sürede bir çeşit perhiz yaparak et yemezler, içki içmezler. ${ }^{34}$

\section{d) Yedinci Ay Orucu}

Yedinci Ay (10 Tevet) orucunun diğer adı "Tzom Gedalya Orucu”dur. Tişri ayının (Ekim) üçüncü günü, I. Sürgün esnasında Kudüs'te kalan Yahudilerin lideri konumundaki Yahuda valisi Gedalya'nın anısına tutulan bir oruçtur. İstila döneminde pek çok Yahuda şehri yerle bir edilirken Bünyamin kabilesine dokunulmamıştır. Ahikam'ın oğlu Gedalya,

\footnotetext{
${ }_{28}$ Alalu vd., Yahudilikte Kavram ve Değerler, 44; Özen, Yahudilikte İbadet, 212.

29 Zekerya 8:19.

30 Fasting and Fast Days. Jewish Virtual Library The Project of Aice. 2011. https://www.jewishvirtuallibrary.org/fasting-and-fast-days-2, 10/05/2021.

${ }^{31}$ Levin, Yahudi Ruhaniliği ve Mistisizmi, 241.

32 Zekerya 7:5; 8:19.

33 Alalu vd., Yahudilikte Kavram ve Değerler, 35-36; Levin, Yahudi Ruhaniliği ve Mistisizmi, 241.

34 Demir, “Diğer İnanç Sistemlerinde ve İslam'da Oruç”, 1788.
} 
Yahuda'da kalan halkın üzerine Nebukadnessar tarafından bu topraklarda düzeni koruması için vali tayin edilmiştir. Kudüs'ün işgal edilince Gedalya ve maiyetindekiler öldürülmüştür. ${ }^{35}$ Gadelya Musevi şehitlerden sayıldığ1 için bu gün anısına oruç konmuştur. İmsak vakti sabahleyin şafak sökümüyle başlar. Bu olay Yeremya Kitabı'nda anlatılır. Bu oruç gün doğuşundan batışına kadar sürer. Bu gün Şabat'a rastladığında bir sonraki gün tutulur. ${ }^{36}$ Yom Kipur'dan yedi gün önce tutulan bu oruç, şafağın sökmesiyle başlar, güneşin batmasıyla son bulur. Oruç süresince dünyevi işlerle uğraşmak yasak değildir. ${ }^{37}$

\section{e) Onuncu Ay Orucu}

"Asarah be Tevet" olarak da bilinen Onuncu Ay (3 Tişri) orucu, M.Ö. 586 yıllarında Kudüs'ün Babil kralı Nebukadnessar tarafından ele geçirilmesi ve yıkılıp yakılması anısına tutulur. Gün boyu tutulan bu oruçta yalnızca yeme içme yasağı uygulanır. ${ }^{38}$

\section{f) Ester Orucu}

Ester, Babil Kralı Nabukadnessar'ın sürgün ettiği Yahudilerin soyundan bir kız olup, Mordekay tarafından yetiştirilmiş ve Kral Ahaşveroş'la evlendirilerek kraliçe olmuştur. Birinci Mabed'in yıkılmasından sonra Pers ülkesine sürgün edilen Yahudiler hakkında Kral Ahaşveroş döneminde (M.Ö. 486-465) topluca öldürülme kararı alınmıştır. Bunun üzerine Yahudiler 13 Adar günü topluca oruç tutmuşlardır. Kraliçe Ester'in girişimiyle bu karar iptal edilerek Yahudiler katliamdan kurtarılmıştır. ${ }^{39}$ Bu hadisenin anısına 14 Adar günü Purim Bayramı kutlanır. Bayramdan bir gün önce de bu oruç tutulur. Tevrat'ta belirtildiğine göre bunda Kraliçe Ester' in Yahudilerden oruç tutmalarını istemesi de etkili olmuştur. ${ }^{40} \mathrm{Bu}$ oruç da önceki üç oruç gibi tutulduğu halde onlardan tek fark1, üzücü bir hadiseye değil, sevinçli bir gelişmeye bağlı olmasıdır. ${ }^{41}$

\subsubsection{Hususi Oruçlar}

Herkesin yapmakla yükümlü olmadığı, bireysel tercihe bağlı olan "Taanith Yahd" adlı özel oruçlar da vardır. Kişi bir yakınını kaybettiğinde, kötü bir rüya gördüğünde veya bir sıkıntı ile karşılaştığında adak olarak oruç tutabilmektedir. Hususi oruçlarda süre, gün doğumuyla başlar, gün batımıyla biter. Kuralları daha esnektir. ${ }^{42}$ Yerel ve bireysel birçok hususi oruç olmakla birlikte burada dokuz tanesi ele alınacaktır.

\section{a) İlk Doğan Orucu}

Mısır'da Firavun, Hz. Musa'nın doğacağını öğrenince İsrailoğulları soyundan doğan erkek çocuklarının öldürülmesine hükmetmiştir. Bunun üzerine Hz. Musa, Allah'ın yardımı

\footnotetext{
35 II. Krallar 25:22-26; Yeremya 40:7.

${ }^{36}$ Herr, "Fasting and Fast Days", 6/722; Besalel, Yahudilik Ansiklopedisi, 183; Yitik, "İzmirli İsmail Hakkı ve Diğer Dinlerde Oruç", 227.

37 Tahir Olgun, Müslümanlıkta İbadet Tarihi (Ankara: Akçă̆ Yayınları, 1998), 126; Özen, Yahudilikte İbadet, 178. II. Krallar 25.25.

38 Herr, "Fasting and Fast Days", 6/722.

39 Karesh vd., Encyclopedia of Judaism, 145; Mehmet Soysaldı, Kur'an ve Sünnet Işı̆̆ında İbadet Tarihi (Elazı̆̆: TDV Yayınları, 1998), 95.

40 Ester 4:16; 9:18, 19, 31.

41 Karesh vd., Encyclopedia of Judaism, 146.

42 J. Milgrom, "Fasting and Fast Days", Encyclopedia Judaica Second Edition, ed. in Chief, F. Skolnik, (Detroit: Thomson\& Gale, 2007), 6/720; bk. "Fasting and Fast Days", Jewish Virtual Library The Project of Aice. 2011. https://www.jewishvirtuallibrary.org/fasting-and-fast-days-2, 10/05/2021.
}

Journal of Analytic Divinity, https://dergipark.org.tr/tr/pub/jad Volume 5/2 
sayesinde mucizevi olarak kurtulmuştur. İşte bu sevinçli olay üzerine şükran olarak orucuna "ilk doğan kişinin orucu" (taanit bekhorim) tutulmaktadır. Oruç tutma yaşına girmemiş çocuğun yerine annesi veya babası tutar. Fısı bayramı arifesinde ailenin en büyük erkek çocuğu geleneğe uyarak oruç tutar.43

\section{b) İzdivaç Günü Orucu}

Talmud'da yer almamakla birlikte gelin ve damadın nikâh günlerinde oruç tutma geleneği vardır. Bu orucun iki gerekçesinden biri, düğün günlerinde gelin ve damadın günahlarının affedildiğine inanılması; ikincisi ise düğün öncesi sarhoş edici içeceklerin içilmesinin önüne geçmektir. Dügüun gününün Roş Hodeş günü veya küçük festivaller ile çakışması halinde bu oruç tutulmaz. Bazı Yahudiler nikâh kıyıldıktan sonra Sinangog'dan ayrılıncaya kadar kısa süreli bir perhiz uygulamaktadırlar. ${ }^{44}$

\section{c) Matem Orucu}

Yahudiler birinci dereceden ölü yakınları, ölüleri için matem orucu tutmakta, bazıları bunu yedi güne tamamlamaktadırlar. Bu oruç, gün doğumuyla başlar, gün batımında son bulur. Yas tutanlara oruç bozmaları için matem ekmeği ve teselli kâsesi ikram edilir. Yaygın olmamakla birlikte bazı Yahudilerin anne babaları veya öğretmenlerinin ölüm yıl dönümünde oruç tutmaktadırlar. 45

\section{d) Küçük Yom Kippur Orucu}

Bazı Musevi cemaatler, genellikle Hamursuz Bayramını takip eden Pazartesi ve Perşembe, Çadır Bayramını izleyen Pazartesi günleri ve Fısıh Bayramından sonra Küçük Yom Kippur orucu tutarlar. Fısıh Bayramından sonraki Küçük Yom Kippur, Nisanın 19'unda başlayıp bir hafta sürer. Mısır'dan çıkışın hatırasına tutulur. Her ayın sonunda tutulan oruca da küçük Yom Kippur denmektedir. 46

\section{e) Özel Oruçlar}

Sinagog'un bir tehlike veya olağanüstü bir durum sebebiyle koyduğu özel oruçlar genellikle Pazartesi ve Perşembe günleri büyük ayin ile icra edilir. Fakat Yom Kippur, Şabat veya bayramlara denk geldiğinde oruç tutulmaz. ${ }^{47}$ Belirli oruçlar dışında afet tehlikesi ve kuraklık zamanlarında tövbe ve pişmanlık duyguları içinde tutulan oruçlar da vardır. Ayrıca Karailer'in Haman'ın zulmünden kurtuluşun anısına tuttukları hususi oruçlar vardır. Bunlar, yetmiş günlük oruç, her ayın yedinci günü tutulan oruç ve Purim'de iki gün olarak tutulan oruçtur. Roş ha-Şana ile Yom Kippur arasında tutulan on günlük tövbe orucu, bayramlarda sarhoşluk ve oburluğun kefareti olarak ayda üç gün tutulan oruç, ay başındaki Pazartesi, Perşembe ve devamındaki Pazartesi günleri orucu, 17 Tamuz-9 Av

\footnotetext{
${ }^{43}$ Karesh vd., Encyclopedia of Judaism, 154.

${ }^{44}$ Asife Ünal, "Yahudi Düğün Gelenekleri”, İnsan ve Toplum Bilimleri Araştırmaları Dergisi 5/2 (2016), 230; Arıkl1, Dinler Tarihi Ansiklopedisi, 154.

45 Ahmet Güç, "Yahudilik'te Defin ve Sonrasına Ait Gelenekler”, Uludă̆ Üniversitesi İlâhiyat Fakültesi Dergisi 10/1 (2001), 77-78; Olgun, Müslümanlıkta İbadet Tarihi, 104.

46 Herr, "Fasting and Fast Days", 6/722; Olgun, Müslümanlıkta Ibadet Tarihi, 104.

47 Herr, "Fasting and Fast Days", 6/722; Cilac1, İlahi Dinlerde Oruç, Hac ve Kurban,198.
} 
arasındaki üç haftalık yas günleri orucu, her ayın son günü tutulan oruç, özellikle dindarların riayet ettikleri hususi oruçlardır. ${ }^{48}$

\section{f) Şahsi Oruçlar}

Bazı Yahudiler, yaşanmış bireysel hadiseleri hatırlama veya affettirme, musibet anında Tanrı'ya sığınma, kötü rüya görme, bir yakınını kaybetme gibi gerekçelerle şahsi olarak oruç tutabilmektedir. Bunlar da aynı şekilde gün doğumundan gün batımına kadar tutulur. ${ }^{49}$

\section{g) Yeni Hilal Öncesi Tutulan Oruç}

Bazı Yahudi cemaatleri, yeni hilalden önce de oruç tutmaktadır. Bu oruç Yahudiler tarafından ezilmişliği kaldırmak ve hürriyeti kazanmak amacıyla tutulmaktadır. ${ }^{50}$

\section{h) Davud Orucu}

Kitab-1 Mukaddes'te zikredildiğine göre, Hz. Davud, Uriya'nın karısının kendisinden olan çocuğu hastalanınca onun iyileşmesi için Allah'a yalvarıp oruç tutmuştur. ${ }^{51}$ Hadislerde Hz. Davud'a nispetle bir gün yiyip bir gün oruç tutma şeklinde uygulanan bir oruç türünden bahsedilmektedir. Bu oruç, İslam'dan önceki Arabistan müşrikleri tarafından tutulan "Dehr orucu" na benzemektedir. 52

\section{i) Sükût Orucu}

Sükût (susma) orucu, sabahtan akşama kadar konuşmayarak nefsi terbiye etme şeklinde tutulur. Bu orucu özellikle dindarlar tutar. Hz. Musa, Hz. Meryem ve Hz. Zekeriya'nın sükût orucu tuttukları bilinmektedir.53 Günümüzde Hahamlar bu orucu tavsiye etmektedir. ${ }^{54}$

\section{Huristiyanlıkta Oruç}

\subsection{Hıristiyanlıkta Orucun Kaynağı, Amacı ve Uygulanışı}

Oruç, Hıristiyanlığın ibadet sistemi içinde önemli bir yer işgal eder. Fakat orucun bir ibadet olarak ikinci asırda mı yoksa üçüncü asırda mı kurumsallaştığı konusunda ihtilaf vardır. Üçüncü asırda, büyük günah işleyen kişinin tekrar Hıristiyan cemaatine katılabilmesi, günahını itiraf etmesine, uzun bir süre kendine eziyet ederek, oruç tutarak, dua ederek ve sadaka vererek hak ettiği cezayı çekmesine bağlanmıştır. ${ }^{55}$ Oruç, kişinin ruhsal olanı aramak için yiyecek ve içecek gibi şeylerden belli bir süre uzak durmasıdır. ${ }^{56}$

Hz. İsa, Ferisi şakirtler oruç tuttuğu halde kendi şakirtlerinin niçin oruç tutmadıklarını soranlara şöyle demiştir: "Güvey kendileriyle beraber oldukça siz düğündekiler hiç oruç tutabilir misiniz? Fakat güveyin onlardan alınacağı günler gelecektir ve o günlerde oruç

\footnotetext{
48 Herr, “Fasting and Fast Days", 6/721-722; Özen, Yahudilikte İbadet, 179, Büyükkaya, İlahi Dinlerde Oruç, 46. 49 Özen, Yahudilikte İbadet, 179-180; Cilac1, İlahi Dinlerde Oruç, Hac ve Kurban, 198.

50 Soysaldı, Kur'an ve Sünnet Işı̆̆ında İbadet Tarihi, 96.

51 II. Samuel, 12/15-23; bkz. Milgrom, "Fasting and Fast Days", 6/719-721

52 Olgun, Müslümanlikta İbadet Tarihi, 161.

53 Hasan Tahsin Feyizli, İslam'da ve Diğer İnanç Sistemlerinde Oruç-Kurban (İstanbul: Milli Eğitim Basımevi, 1993), 27; Olgun, Müslümanlıkta İbadet Tarihi, 104. Ayetler için bk. Meryem, 19/26; Al-i İmran, 3/41

54 Büyükkaya, İlahi Dinlerde Oruç, 47.

${ }^{55}$ K. Bihlmeyer - H. Tuchle, I. ve IV. Yüzyıllarda Hıristiyanlık, çev. A. Göral (İstanbul: Güler Matbaası, 1972), 92.

56 Ali Erbaş, Hıristiyanlıkta İbadet (İstanbul: Ayışı̆̆ı Yayınları, 2003), 53.
} 
tutacaklardır." $57 \mathrm{~Hz}$. İsa, dini bir ibadet olarak oruç tutmaya karşı olmadığ1 gibi bunu inananlarına bizzat tavsiye etmiştir. Hatta orucun samimiyetle tutulması gerektiğine dair şu uyarıyı yapmıştır: "Oruç tuttuğunuz zaman ikiyüzlüler gibi surat asmayın. Onlar oruç tuttukların insanlara belli etmek için kendilerine perişan bir görünüm verirler. Size doğrusunu söyleyeyim, onlar ödüllerini almışlardır. Siz oruç tuttuğunuz zaman başınıza yağ sürüp yüzünüzü yıkayın. Öyle ki insanlara değil, gizlide olan Babanıza oruçlu görüneceksiniz. Gizlilik içinde yapılanı gören Babanız sizi ödüllendirecektir."58

Oruç, Hz. İsa döneminde ve Hıristiyanlığın ilk yıllarında çok takdir edilen bir ibadet olmuştur. ${ }^{99}$ Kaynaklardan Hz. İsa'nın vaazlarına başlamadan önce kırk gün oruç tuttuğu, ayrıca Yahudilikteki "Kefaret" orucunu da eda ettiği anlaşılmaktadır. İncil'de: "İsa, kırk gün kırk gece oruç tuttuktan sonra acıktı."60 bilgisi yer almaktadır. Hz. İsa, oruçla ilgili açık hükümler koymamış, sadece bazı ilkeler bırakmış, hüküm koyma hususunda Kiliseyi yetkilendirmiştir. Bu konuda Yoel'de şöyle söylenmektedir: "Oruç takdis edin, toplantrya çă̆ırın, ihtiyarları ve memlekette oturanların hepsini Allah'ınız olan Rabbin evine toplayın ve Rabbe feryat edin." 61 Ayrıca Barnabas ve Pavlus'un ilk Antakya yolculuğunda halkın sevinçten oruç tuttuğu haber verilmektedir. ${ }^{62}$

Hıristiyanlıkta oruç, insan ile Tanrı arasında kalan bir ibadettir ve yalnızca Tanrı'nın rızasını kazanmak niyetiyle yapılır. Kişinin oruç tutarken alçakgönüllü davranması gerekir. ${ }^{63}$ Oruç tutmanın gerekçeleri, Tanrının gücünü kişisel olarak tecrübe etmek, Tanrı'nın vaatlerini yerine getirmek, son peygamberin yeniden açığa çıkması, kötülüklerden korunmak, doğru yolu bulmak ve düşülen krizden kurtulmak şeklinde sıralanmaktadır. ${ }^{44}$ Aynı zamanda evlilik, tövbe, yeni bir vazifeye başlama, iş değiştirme, göç etme, sevinç veya üzüntü, ödül, gururun kırılması, acizlikten kurtulma, Tanrı'dan kuvvet isteme ve Tanrı' ya sı̆̆ınma da oruç tutmada etkili olan gerekçelerdir. ${ }^{65}$

Calvin'e göre orucun üç hedefi vardır: (i) Bedenin her arzusunu yapmaması için direncini azaltarak boyun eğdirmek, (ii) dualara ve kutsal düşünmeye daha iyi hazırlanmak, (iii) Tanrı' nın önünde günahları itiraf etmek alçalmaktır. ${ }^{66}$ Oruç ve dua, Hıristiyan inancının iki temel taşı olup insana açlık ve yoksulluğun acısını yaşama fırsatı verir; başkaları uğruna egodan vazgeçmeyi ifade eder. Hıristiyanlıkta oruçlar üç grupta ele alınmaktadır: Birincisi, Tanrı'nın "davet" $i$ olarak tutulan oruçtur. İkincisi, kişinin günahlarını hatırlamasını, günahlarından dolayı acı çekmesini, dolayısıyla bağışlanıp ruhen güçlenmesini sağlayan

\footnotetext{
57 Luka 5:33-35.

${ }^{58}$ Matta 6:16-18

59 Marc Ague, Paganizmin Dehası, çev. E. Atacay (Ankara: Dost Kitabevi Yayınları, 2010), 214.

${ }^{60}$ Matta 4:2.

61 Yoel 1:14

62 Resullerin İşleri 13:1-3

${ }^{63}$ Erbaş, Hiristiyanlikta İbadet, 51-55.

${ }^{64}$ M. Bickle - D. Candler, The Rewards of Fasting, Frounner Books (Kansas City: 2005), 24-34.

65 Erbaş, Hiristiyanlikta İbadet, 56.

${ }^{66}$ J. Calvin, The Institutes of the Christian Religion, trans. H. Beveridge (Grand Rapids: Public DomainRights, 2002), 757.
} 
"kefaret" oruçtur. Üçüncüsü, kişinin gönüllü olarak zayıflık çekmesi sebebiyle Tanrı'nın lütfunu kazanmasına vesile olan "zarafet" orucudur. ${ }^{67}$

Hıristiyanlıkta oruç açlık, susuzluk, nefse eziyet, sıkıntı, darlık, hapis gibi nefse ağır gelen iş ve davranışlarla birlikte anılmaktadır. Kişi, oruç yoluyla bedenine eziyet ederek kötü duyguları yok eder, kendini bu dünyada cezaya alıştırır, gururunu kırar ve günahına tövbe eder. ${ }^{68}$ İncil'deki ifadelerden oruç ile perhizin aynı anlamda kullanıldığı anlaşılmaktadır. Buna göre oruç, ruhsal olanı elde etmek için yiyecek ve içecek gibi bazı şeylerden belli bir süre uzak durmak, perhiz yapmaktır. Oruç, yaşamın yeme içmeden ibaret olmadığını hatırlatarak ruhsal yöne dikkat çekmektedir. ${ }^{69}$

Oruç ve perhiz, günahlara kefaret olur ve nefsin arzularını kontrol altında tutar. Hastalar, düşkünler, çocuklar, ağır işlerde çalışanlar ve askerler dışında her Hristiyan oruç tutmakla yükümlüdür. Oruç tutabilecekken tutmayanlar daha sonra tutamadıkları oruçları telafi edebilirler. Kilisede görevli din adamları gerektiğinde kendi kilisesine devam eden Hıristiyanların orucunu bozdurma yetkisine sahiptir. Oruç yaşı kısmi perhizde 14, tam perhizde 21-60'tır. Oruçlu, öğle veya akşam öğünlerinden yalnızca birinde yemek yiyebilir. Bunun dışında her zaman hafif şeyler tüketebilir. Oruçluyken sigara vb. keyif verici maddeler kullanmak yasaktır. ${ }^{70}$

Hıristiyanlığın yayıldığı ilk zamanlarda Çarşamba ve Cuma günleri oruç tutulmuştur. Çünkü Çarşamba orucu, Hz. İsa'nın ele verildiği günü, Cuma orucu çarmıha gerildiği günü temsilen tutulmuştur. Cumartesi de onun gömüldüğü gün olarak oruç tutulur. Hiristiyanlıkta oruç tarihi süreç içinde çeşitli düzenlemelere tabi tutulmuştur. M.S. dördüncü yüzyıldan itibaren orucun hüküm ve uygulaması katı kurallara bağlanmıştır. Paskalya öncesi iki gün oruç tutma geleneği, dindar Hristiyanlar tarafından hâlâ yerine getirilen bir ibadet olamaya devam etmektedir. M.S. beşinci yüzyıl sonrasında Batı kiliselerinin etkili olduğu bölgelerde Çarşamba orucunun yerini cumartesi orucu almıştır. Paskalya'da ve her mevsim başında tutulan üç günlük oruca yıl boyunca tutulan on iki günlük oruç da ilave edilmiştir. Ortaçağda değişik bölgelerde yaşayan Hıristiyanlar ülkesine ve zamanına göre değişen bazı oruç günleri ihdas etmişlerdir. Anglikan Kilisesi Reform'dan sonra oruç günlerini bir takvime göre düzenlemiş, ancak uyulacak şartlar ve hükümler konusunda esneklik göstermiştir. ${ }^{71}$

Orucun vakti, tutma şekli, hükümleri ve uyulacak kurallar bakımından Hiristiyan mezhepleri arasında ülkeden ülkeye değişen bazı uygulama farklılıkları vardır. ${ }^{72}$ Oruca başlama yaşı mezheplere göre farklılık gösterir. Katoliklere göre oruç tutma yükümlülüğü yirmi yaş dolunca başlar, altmış yaşında kalkar. ${ }^{73}$ Ortodoks ve Süryani kiliselerinde oruca on dört - on beş yaşlarında başlanır. ${ }^{74}$ Kiliselerde görevli papazlar kendilerine bağlı olanlara

\footnotetext{
67 Bickle - Candler, The Rewards of Fasting, Frounner Books, 22-24.

68 Resullerin İşleri 6: 5, 11:27; Matta 6:16-18; Yeşaya 3:1-3; 12

${ }^{69}$ Cilac1, İlahi Dinlerde Oruç, Hac ve Kurban, 27; Küçük vd., Dinler Tarihi, 395.

70 Ali İhsan Yitik, "Oruç”, TDV İslam Ansiklopedisi (İstanbul: TDV Yayınları, 2007), 28/415; Feyizli, İslam'da ve

Diğer İnanç Sistemlerinde Oruç-Kurban, 33-34.

71 Yitik, "Oruç", 415; Gluseppe Descuffi, Hiristiyan Dini (İzmir: yy, 1963), 143-144.

72 Erbaş, Hiristiyanlıkta İbadet, 60.

73 Descuffi, Hiristiyan Dini, 143.

74 Yitik, "Oruç", 33/415.
}

Journal of Analytic Divinity, https://dergipark.org.tr/tr/pub/jad Volume 5/2 
gerektiğinde oruç bozdurabilir. Herhangi bir Hıristiyan da acil durumda kendi vicdanıyla karar vererek orucunu bozabilir. ${ }^{75}$

\subsection{Hıristiyanlıkta Oruç Çeşitleri}

Hıristiyanların yaşadıkları ülkeye göre değişiklik gösteren oruç uygulamaları vardır. Bazıları etten, bazıları balıktan uzak durur. Bazıları meyve, yumurta veya lüks yiyecekler yemezken, bazıları hepsinden kaçınmaktadır. Sıvı tüketmek genel olarak serbesttir. Oruç, Doğu Kiliselerinde sıkı kurallara bağlı iken, Batı'daki Kiliselerde hafif ve sadedir. ${ }^{76}$ Ortodokslar, Katolikler ve Anglikanlar oruca riayet ettikleri halde bazı Protestan gruplar oruç tutmayı reddetmektedirler. ${ }^{77}$

Yahudilik ve İslam'dan farklı olarak Hıristiyanlıkta oruç daha çok bireysel tercihe bırakılmıştır. Bundan dolayı ikili tasnif yapılarak Hıristiyanların çoğunluğu tarafından yerine getirilen oruçlar "Genel oruçlar" başlığı altında, azınlık tarafından tutulan oruçlar ise "Hususi oruçlar" başlığı altında incelenmektedir.

\subsubsection{Genel Oruçlar}

Genel oruçlar, çoğunluğun riayet ettiği oruç çeşitleridir. Bunlar dört madde olarak ele alınacaktır.

\section{a) Ökaristik (Şükran) Orucu}

Ökaristik oruç (Evharistiya) her hafta Pazar günü icra edilen, şaraplı ekmek yemeden önce belli bir süre kişinin kendisini her türlü yiyecekten veya yalnızca katı yiyeceklerden mahrum etmesi şeklinde tutulan bir şükran orucudur. ${ }^{78}$ Evharistya, ikinci yüzyıl başlarından itibaren Hıristiyan inanç ve ibadet sisteminin esasını oluşturan ikinci sakrament olarak kabul edilmiştir. Başlangıçta basitçe ekmeği bölme şeklindeyken daha sonra ekmek ve şarap unsurları "sır" niteliği kazanarak günahların kefareti olmuş, Tanrı'ya yaklaşma vesilesi haline gelmiştir. Evharistya, Hz. İsa' nın Havarileriyle birlikte yediği son akşam yemeğinin sembolüdür. Ekmek ve şarap, Hz. İsa'nın kendi vücudunu ve kanını temsil etmektedir.79

Evharistik ayin (Missa) iki bölümden oluşmaktadır. Birinci bölümde Kutsal metinler okunur, Rahibin vaazı dinlenir ve cemaat halinde dualar edilir. İkinci bölümde Rahip sunağa gider, kutsal ekmekleri ve şarap kupasını Tanrı'ya sunar. Ardından Rahip ile cemaat bir süre konuşurlar ve koro halinde ilahiler okunur. Evharistya duası ile birlikte Rahip ekmek ve şarapları kutsar. Bu duanın sonunda Baba, Oğul ve Kutsal Ruh anılır, Hz. İsa'ya Hz. Yahya tarafından söylenen sözler üç defa tekrarlanır. Sonunda cemaate

\footnotetext{
75 Descuffi, Hiristiyan Dini, 143

76 Ahmad, "Fasting in Religions", 33.

77 Büyükkaya, İlahi Dinlerde Oruç, 58-59.

78 Küçük vd., Dinler Tarihi, 396.

${ }^{79}$ Ahmet Hikmet Eroğlu, “Ekmek-Şarap Ayini (Eyharistiya) Konusunda Katolikler ve Protestanlar Arasındaki Anlayış Farklılıkları", Ankara Üniversitesi İlahiyat Fakültesi Dergisi 39/1 (1999), 441; Yuhanna 6:53-55, Luka 22:19; Markos 14:22-24.
} 
kutsanmış ekmek ve şarap dağıtılır. Bu ayine "Komünyon alma" denir. ${ }^{80}$ Komünyon almadan önce yiyecek ve içecekten tam kaçınarak Evharistik perhiz yapılır. Bu sakrament, Doğu kiliselerinde güneşin doğuşuyla birlikte başlamaktadır. Roma Katolik kilisesinde oruç süresi bir saate indirilmiştir. Uygulama, gecenin on ikisinden Komünyon zamanına kadar hiçbir şey yiyip içmemek şeklinde yapılır. Günümüzde ise Komünyondan bir saat önce su ve ilaç dışında bir şey almama ve üç saat öncesinden alkol kullanmama şeklinde uygulanmaktadir. ${ }^{81}$

\section{b) Ekleziyastik (Kiliseye Mensubiyet) Orucu}

Ekleziyastik, Kiliseye mensubiyetin ifade edildiği bir perhizdir. Paskalya bayramı öncesine denk gelen bu oruç, Hz. İsa' nın vaftiz olduktan sonra çölde 40 gün oruç tutmasının hatırasına konulmuştur ve perhiz şeklinde yapılır. Bu oruç, Anglikan Kilisesi dışındaki tüm Hristiyan kiliseleri tarafından kabul edilmektedir. Kiliselerin değişik şekillerde uyguladığı en uzun oruçtur. Paskalyadan önceki 40 güne tekabül etmektedir. ${ }^{82}$ Kilise, Lent döneminde 83 insanları günahlarından kurtulmaları için 40 günlük "kefaret" perhizine davet eder. Bu süreç, manevi arınma ve Paskalya bayramına hazırlık olarak görülmektedir. ${ }^{84}$

Paskalya, Hz. İsa'nın dirilip göğe yükselişinin hatırası kabul edilmektedir. Paskalya, Nisan'ın on beşinden sonraki ilk Pazar günü olarak belirlendiği için kırk günlük perhiz süresidir. Günümüzde Hristiyanlar, Hz. İsa'nın çölde tuttuğu oruç hatırasına 21 Mart'tan sonraki dolunayı izleyen ilk Pazar yani Paskalya öncesinde sona erecek şekilde 40 gün oruç tutarlar. Pazar günü oruç tutmak yasak olduğu için bu günler çıkıldığında toplam 34 gün oruç tutulmuş olur. Paskalya günlerinde diğer zamanlarda yenilen yiyeceğin üçte ikisi kadar yenir, balık dişında hayvani gıda tüketilmez. Günümüzde Roma Katolik Kilisesi'nin koyduğu yasa gereği et, süt, peynir ve yumurtadan perhiz yapılmaktadır. Kutsal Hafta içinde perhize ekmek, tuz, kuru gıda, sebzeler ve alkol de dâhil edilir. ${ }^{85}$

\section{c) Noel Orucu}

Hz. İsa'nın doğum yıldönümünde yapılan kutlamalara Noel Bayramı denir. Bu zaman dilimi Kilise takviminde "1şık döngüsü" adıyla yer alır. Hz. İsa ile ilgili olarak kutlanan ilk bayram Noel ve Noel'e hazırlık anlamındaki Advent dönemidir. ${ }^{86}$ Noel'e kadar devam eden bu dönem, dört Pazardan oluşan bir süreyi içine almaktadır. Hıristiyanlığın ilk dönemlerinde böyle bir kutlama görülmemektedir. Bu gelenek Noel Bayramı olarak Batı' da IV. yüzyıldan itibaren her yıl 25 Aralıkta kutlanmaya başlamıştır. ${ }^{87}$

Advent döneminde sıkı bir kefaret uygulaması kapsamında iki tür oruç söz konusudur. Birincisi Ember günlerinde tutulan oruç, ikincisi Noel orucudur. Noel

\footnotetext{
80 Mehmet Aydın, “Hıristiyanlık”, TDV İslam Ansiklopedisi (Ankara: TDV Yayınları, 1998), 349; Şinasi Gündüz, Din ve İnanç Sözlü̈̆̈̈̈ (Ankara: Vadi Yayınları, 1998), 122- 123.

81 Gündüz, Din ve Innanç Sözlüğ̈̈, 221-222; Küçük vd., Dinler Tarihi, 396.

82 Ahmad, "Fasting in Religions", 34.

83 J. F. Sulliven, The Externals of the Catholic Church, Rev. J. C. O'Leary (New York: Kenedy, 1951), 209.

${ }^{84}$ Gündüz, Din ve İnanç Sözlüğ̈̈̈, 234.

85 Gündüz, Din ve İnanç Sözlü̈̆̈̈̈, 234.

86 A. Hughes, Medival Manuscripts for Mass and Office (Toronto: A Guide to Their Organization and Terminology, 1995), 6; Sulliven, The Externals of the Catholic Church, 199.

87 Hughes, Medival Manuscripts for Mass and Office, 4; Sulliven, The Externals of the Catholic Church, 185; Küçük vd., Dinler Tarihi, 388.
}

Journal of Analytic Divinity, https://dergipark.org.tr/tr/pub/jad Volume 5/2 
kutlamalarının değiştiği günümüzde birçok Hıristiyan oruç tutmamakta, yalnızca doğum anı hatırasına yapılan ayinlere katılmaktadır. Katolik Kilisesi Noel orucunu hafifleterek Noel arifesinde yapılan kısa süreli perhize dönüştürmüştür. On gün ile perhiz süresini en çok tutan kilise, Süryani Kilisesidir. Perhiz süresi içinde etli yemekler dâhil bazı yiyeceklerden uzak durulur, bitkisel yağ ile yapılmıs tek çeşitli sebzeli yemek ve balık tüketilir. 88

\section{d) Haftalık Oruçlar}

Kiliseler genel olarak Çarşamba, Cuma ve Cumartesi günlerinde oruç tutmayı teşvik etmekle birlikte bazı mezheplerde oruç günleri Çarşamba ve Cuma ile sınırlıdır. ${ }^{89}$ Haftalık oruç, İncil'deki "Haftada iki kere oruç tutarım, bütün ondahı̆ımı veririm." ayetine dayandırılmaktadır..$^{90}$ Daha önce de belirtildiği gibi bu günler, Hz. İsa'nın Çarşamba günü ele verilmesi, Cuma günü haça gerilmesi, Cumartesi günü defnedilmesi sebebiyle önemlidir. Dindar Hıristiyanlar genel olarak Yortu günlerine rastlamayan her Cuma günü et ve yağlı yemeklere karşı perhiz yaparlar..$^{91}$

\subsubsection{Hususi Oruçlar}

Hususi oruçlar ile dindarların bireysel tercihleriyle tuttukları oruçlar kastedilmektedir. Bazı hususi oruç örnekleri olarak şunlar zikredilebilir: Yıl içinde her mevsim tutulan üç günlük oruç, 21 günlük oruç, Meryem'in göklere çıarılması anısına tutulan 50 günlük oruç, papazların bireysel olarak tuttukları oruç, her cuma balık dışındaki et yemekleri tüketilmeden hafif yemekler yiyerek tutulan oruçlar. Tövbekârların kefaret amacıyla tuttukları oruç ve IV. yüzyıldan itibaren özellikle manastırlarda yaşayan ruhban sınıfının gönüllü olarak tuttuğu oruçlar da bu çerçevede değerlendirilebilir. ${ }^{92}$

Süryani Ortodoks Kilisesi, oruçla ilgili saat uygulamasında esneklik gösterir. Oruç, sabah güneşin doğmasıyla başlar, akşam namazı için kilise çanı çalınca biter. Öğleye kadar oruca niyet edenlerin orucu öğlen namazı sonrasında biter. Süryaniler tıpkı Müslümanlar gibi sabahtan akşama kadar yeme, içme ve cinsel ilişkiden uzak durarak oruç tutarlar. Diğer Hiristiyanlardan farklı olarak sabahtan akşama kadar susuz kalmak suretiyle "susuzluk orucu" da tutarlar. Ayrıca perhiz oruçlarında gün boyunca et yemedikleri gibi, süt, tereyağ1 ve yumurta gibi hayvansal ürünleri de tüketmezler. Yemeklerde yalnızca bitkisel yağ, tahıl ve sebze kullanılır. Büyük oruç dişında Ninova orucu, Elçiler orucu, Meryem ana orucu, Çarşamba ve Cuma oruçları da tutarlar..$^{93}$

\footnotetext{
88 Sulliven, The Externals of the Catholic Church, 198, 205-207; Feyizli, İslam'da ve Diğger Inanç Sistemlerinde OruçKurban, 36.

${ }^{89}$ Sulliven, The Externals of the Catholic Church, 197.

${ }^{90}$ Luka 18:12.

${ }^{1}$ Feyizli, İslam'da ve Diğer İnanç Sistemlerinde Oruç-Kurban, 33.

92 Demir, “Diğer İnanç Sistemlerinde ve İslam'da Oruç”, 1791; Soysaldı, Kur'an ve Sünnet Işı̆̆ında İbadet Tarihi, 107-108.

93 Nihat Durak, Süryani Ortodoks Kilisesinde İbadet (İstanbul: Rağbet yayınları, 2011), 141-143; Feyizli, İslam'da ve Diğer İnanç Sistemlerinde Oruç-Kurban, 36; Demir, “Diğer İnanç Sistemlerinde ve İslam’da Oruç”, 1791.
} 
Ay, Rahim. İlahi Dinlerde Oruç: Kaynağı, Amacı ve Uygulanışı Bakımından Karşılaştırmalı Bir İnceleme

\section{3. İslam'da Oruç}

\section{1. İslam'da Orucun Kaynağı, Amacı ve Uygulanışı}

İslam'dan önce Araplar Cahiliye devrinde Aşûre günü oruç tutarlard1. ${ }^{94}$ Buna dayanarak Muharrem'in onuncu günündeki orucun onlardan kalan bir âdet olduğu söylenebilir. ${ }^{95}$ Cahiliye devrinde Aşûre dişında sükût orucu da vardı. Cahiliye Arapları gün boyunca hiç konuşmazlar, bunu bir ibadet sayarlardı. Ancak Hz. Peygamber bu orucu yasaklamıştır. ${ }^{96}$

İbadetlerin temel amacı kulluk olmakla birlikte çeşitli maksat ve hikmetleri de vardır. Allah'ın emir ve yasak şeklindeki hükümleri insanların yararlarını gerçekleştirmeye matuftur. İman-amel ilişkisinin en somut örneklerinin başında oruç ibadeti gelir. İslam' da oruç ibadetinin farziyeti "Ey iman edenler! Allah'a karşı gelmekten sakınmanız için oruç sizden öncekilere farz kılındığı gibi size de farz kılındı."97 ayetine dayanmaktadır. Oruç, Allah'ın emirlerine uymak ve ona yaklaşmak için yeme, içme ve cinsel münasebet gibi temel beşerî ihtiyaçlardan günün belirli bir vaktinde uzak durması şeklinde ifa edilir. Bu iradeli kaçınma itaat ve takvanın en önemli göstergesidir. Böylece kişi, günahlardan ve her türlü kötülükten sakınma alıştırması yapmış, kötülüklerden kaçınma ve iyi insan olma melekesi kazanır.

Oruç insana kulluk bilinci kazandırır. Diğer ibadetlerden farklı olarak oruçlu kişinin ibadeti dışarıdan görünmez. Riyaya kapalı bu samimi ortamda insan kendini takvaya alıştırır, ruhsal yönden arınır, iradi olarak güçlenir. Oruç aynı zamanda kişide sorumluluk bilinci meydana getirir. Sorumluluk bilincine sahip olan insan, diğer insanlar yanında tüm varlıklara karşı iyi davranır, her türlü haksızlıktan kaçınır. İşte orucun amacını oluşturan takva budur.

İslâm'da farz olan oruç, her yılın Ramazan ayında tutulur. Bu da kameri ayların gereği yıldan yıla 29 veya 30 gün şeklinde değişiklik gösterir. Özrü sebebiyle Ramazan içinde oruç tutamayanlar, zikredeceğimiz ayette açıklandığı gibi diğer aylarda tutamadıkları orucu günü gününe tutarlar. "Sizden kim hasta veya yolcu olursa tutamadiğ günler sayısınca diğer günlerde oruç tutar."98

Kur'an'da oruç süresi "sayıll/belirli günler" ifadesi ile belirtilmiştir. Buradan Allah'ın insanları bir eğitim sürecinden geçirmek istediği anlaşılmaktadır. Tutulamayan orucun yılın diğer aylarında tutulmasının istenmesi, eğitimin tamamlanması gerektiğine yönelik bir vurgudur. ${ }^{99}$ Ramazanda bir ay boyunca yeme ve içme gibi nimetlerden uzak

\footnotetext{
94 Buhari, Savm, 69; Tirmîzî, Savm, 48.

95 Olgun, Müslümanlikta İbadet Tarihi, 122-123.

96 Ebu Davud, Vasaya, 26; Demir, “Diğer İnanç Sistemlerinde ve İslam'da Oruç” 1792.

97 Bakara, 2/183-184.

98 Bakara, 2/184.

99 Bakara, 2/185.
}

Journal of Analytic Divinity, https://dergipark.org.tr/tr/pub/jad Volume $5 / 2$ 
kalan Müslüman bu manevi eğitim sürecine günahlarından arınır ve güzel hasletler kazanır.

Oruç sayesinde varlıklı insanlar yoksulların halini anlayıp yaşadıkları sıkıntıyı gözlerinde canlandırabilir. Muhtaçlara yardım etme duyarlılı̆̆ı gelişir. Oruç, sevgi ve merhamet gibi duyguları artırır, başkalarına yardım etme eğilimini güçlendirir. 100 Oruç tutmaya güç yetiremeyenlerin fidye vermeleri emredilmiştir. ${ }^{101} \mathrm{Hem}$ bu uygulama hem de Ramazan sonlarında verilmesi istenen fitır sadakası toplumdaki yoksulların korunmasına yönelik önemli tedbirlerdir. Bilinçli olarak tutulan oruç sayesinde sosyal anlaşmazlıklar ve huzursuzluklar azalır.

Ramazan ile Kur'an arasında özel bir ilişki vardır. Çünkü Kur'an bu ayda indirilmeye başlamıştır. ${ }^{102} \mathrm{Bu}$ yönüyle orucun eğitim ve öğretimle alakası vardır. Ramazan ayında mukabele tarzında okunan Kur'an, Müslümanların Kur'an mesajını yeniden kapsamlı olarak hatırlamalarını sağlar.

İslam fıkhında oruçla ilgili hükümler ayrıntılı olarak belirlenmiştir. Orucun farzları, vacipleri, müstehapları, edepleri, oruçluya haram ve mekruh olan durumlar vardır, ancak bu çalışma bir fıkıh araştırması olmadı ̆̆ 1 için bu türden ayrıntıya girilmeyecektir. Ergenlik çağına giren her erkek ve kadın oruç tutmakla yükümlüdür. Orucun ertelenmesini, tümden muaf tutulmayı veya fidye vermeyi gerektiren haller ve şartlar fıkıh kitaplarında genişçe ele alınmaktadır. 103

\section{2. İslâm'da Oruç Çeşitleri}

a) Farz Oruç: Akıllı ve ergenlik (buluğ) çağına girmiş olan her erkek ve kadın Müslümana Ramazan orucu farzdır. Bir mazereti sebebiyle tutamayanlar daha sonra günü gününe kaza ederler.

b) Vacip Oruç: Nezir (adak) orucu ve bozulmuş nafile orucun kazası vacip oruç kapsamina girer.

c) Nafile Oruç: Farz ve vacip dişında kalan oruçlar nafile sayılır. Şevval orucu, ${ }^{104}$ Aşûre orucu, ${ }^{105}$ her ay üç gün tutulan oruç, ${ }^{106}$ Pazartesi ve Perşembe orucu, ${ }^{107}$ Zilhicce orucu, ${ }^{108}$ Haram aylarda tutulan oruç, Şaban ayında tutulan oruç, Davud orucu ${ }^{109}$ nafile

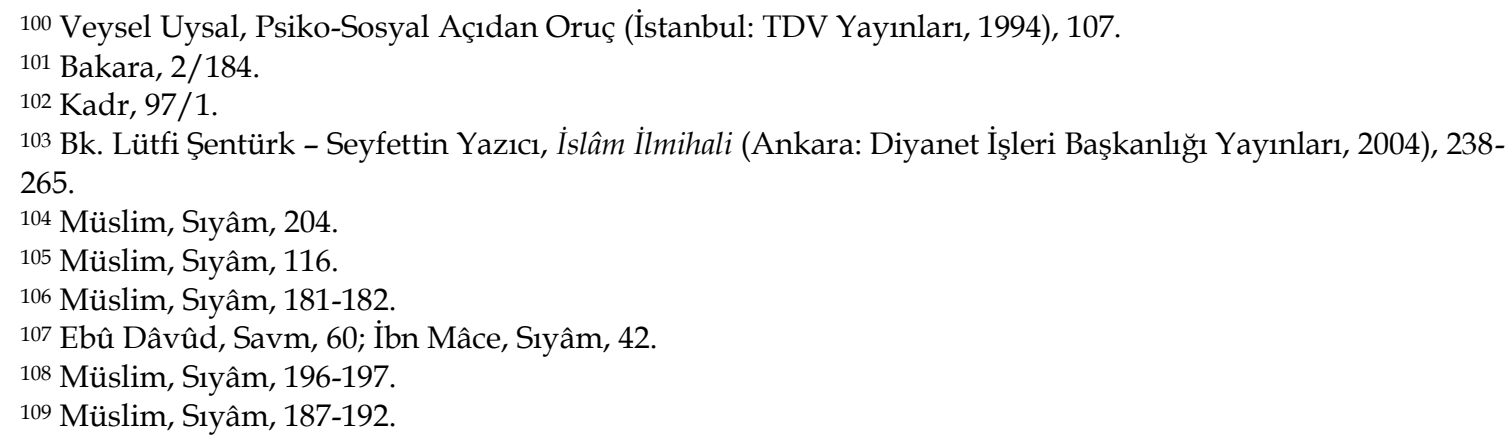


Ay, Rahim. İlahi Dinlerde Oruç: Kaynağı, Amacı ve Uygulanışı Bakımından Karşılaştırmalı Bir İnceleme

oruçlar kategorisinde yer alır. Ayrıca bir Müslümanın Ramazan ayı dışında istediği herhangi bir gün gönüllü olarak tutacağı oruç da nafile sayılır. ${ }^{110}$

Oruç tutmanın mekruh veya haram sayıldığı durumlar da vardır. Bayram günlerinde oruç tutmak, yevm-i şek orucu, visal orucu, dehrî oruç bu türden oruçlardır. ${ }^{111}$

\section{4. İlahi Dinlerde Orucun Amaç, Kaynak ve Uygulanışı Bakımından Mukayesesi}

Üç ilahi dindeki oruçlar, amaç ve manası bakımından birbirine yakın iken, süresi ve uygulanışı bakımından bazı farklılık göstermektedir. Günün belli bir kısmından aylara kadar değişen riyazet, perhiz ve sükut şekilleri vardır. Oruç günlerinin sayısı, Yahudilikte yirmi günden fazla, Hıristiyanlıkta tüm mezhebi farklılıklarla beraber kırk günden fazla, İslam' da ise otuz günden fazladır.

Oruç, İslam'da olduğu gibi İslam'dan önceki diğer ilahi dinlerde de önemsenen bir ibadettir. "Oruç, sakınasınız diye sizden öncekilere farz kılındı̆̆ı gibi size de farz kılındı." ayeti fiilen uygulanan bir ibadetin Kur'anî bir doğrulamasıdır. Oruç, dinlere, medeniyetlere ve kavimlere göre gerek uygulamada gerekse amaçta bazı farklılıklar göstermektedir. Oruç yerine göre bir ceza, kefaret, Tanrı'nın gazabını yatıştırma, bedenin kuvvet ve şehvetlerini frenleme, eğitim aracı, kaybedilen şerefin iadesi olarak görülmüştür.

Orucun tutulma şeklinde de bazı farklılıklar göze çarpmaktadır. İslam'da tamamen fecri sadığın ortaya çıkışından güneşin batışına kadar yeme, içme ve cinsel ilişkiden uzak durma şeklinde uygulanmasına rağmen diğer dinlerde perhiz, riyazet, sükût gibi şekillerine de rastlanmaktadır. Dinlerde zorunlu oruçların yanında gönüllü (nafile) ve hususi türünden oruçlar da vardır. Ayrıca yıllık, aylık, haftalık şeklinde gruplandırmalar da söz konusudur.

İlahi dinlerin üçünde de oruç tutacak kişilerde asgari şartlar aranmış, yükümlülük çağı sınırlanmış, hastalar, hamileler, özel hallerinde kadınlar ve yaşlılar için bazı muafiyetler getirilmiştir. $\mathrm{Bu}$, dinlerin insan sağlığına ve yükümlülük-istitaat dengesine riayet ettiğini göstermektedir.

Her üç ilahi dinde herkes için mecburi oruçlar bulunmaktayken sadece Yahudilik ve Hıristiyanlıkta din adamları tarafından ihdas edilmiş oruçlar vardır. Orucun kutsal metinlerle desteklenmiş olması onun uygulanması noktasında bir ciddiyet ve disiplini garanti etmektedir. Hususi oruçlarla mezhepler arası ve kişiden kişiye farklılıklar ortaya çıkmaktadır. Özellikle Hıristiyanlıkta kiliselerin oruç uygulamaları şekil ve süre farklılığı göstermektedir. Katolikler orucu katı kurallarla uygulamakta iken, Protestanların çok azı oruca riayet etmektedir. Ortodokslar orta yol izlemekte, Süryaniler ise orucun uygulamasında daha ciddi tutum sergilemektedir. Yahudilik ve İslam'da mecburi/farz oruçtan bahsedilmekte iken, Hıristiyanlıkta buna yakın bir oruç türünü ancak "Genel oruçlar" başlığı altında inceleyebilmekteyiz ki bu mecburiyi bire bir karşılamamaktadır.

Yahudilikte Hahamların oruç ihdas etme yetkisiolduğu için yaşanmış olaylara ve egemen kültüre bağlı olarak çok sayıda değişik oruç çeşitleri ortaya çıkmıştır. Fakat birçoğu ya terk edilmiş ya da uygulamadan kaldırılmıştır. Diğer ikisinin aksine İslam'da hiç

110 İslam'daki oruç çeşitlerinin farklı bir sınıflandırması ile ilgili olarak bk. Büyükkaya, İlahi Dinlerde Oruç, 8198.

111 Bk. İ. Kafi Dönmez, “Oruç”, TDV İslam Ansiklopedisi (İstanbul: TDV Yayınları, 2007), 33/419. Buhârî, Savm, 11, 14; Müslim, Sıyâm, 21; Ebû Dâvûd, Savm, 10. Müslim, Sıyâm, 55-58.

Journal of Analytic Divinity, https://dergipark.org.tr/tr/pub/jad Volume 5/2 
kimsenin oruç ihdas etme yetkisi yoktur. İslam âlimleri sadece içtihat gereği konulmuş orucun hükümlerini naslara göre yorumlamakla yetkilidir. Bu nedenle oruç türü ve şekli aynı kalmakla birlikte uygulamada mezhebi görüş farklılıkları vardır. Yine de diğer iki dindeki kadar belirgin farklılıklar yoktur.

İlahi dinlerde yer alan haftalık oruçlar dinlerin ortak benzer uygulamalarından birisi olduğu görülmektedir. İfade ettiği anlam itibariyle aslında haftalık tutulan oruçlar birbirine yakın anlamlar ihtiva etmektedir. Çünkü haftalık oruç günlerinde bir bağışlanma, affedilme, kötülüklerden korunma inancı ortak olarak yer almaktadır. Dolaysıyla dindar kimseler bağışlanmak ve günahlarından arınmak ümidiyle haftanın belirli günlerini oruçla geçirmektedir. Bu durum oruç ibadetinin dindarlarınhayatında dinamik ve aktüel olarak yer alan bir ibadet olduğunu göstermektedir.

Dinlerdeki mecburi oruçlar nicel açıdan mukayese edildiğinde İslam'ın Yahudilik ile Hıristiyanlık arasında yer aldığı görülür. Yahudilikteki oruç süresi tam perhizli yirmi beş saat iken, Hıristiyanlıktaki oruç süresi en fazla üç saattir. İslam'daki oruç gün doğumu ile batımı arasında tutulduğu için Yahudilik ve Hıristiyanlığa göre vasat bir durumdadır. Zorunlu oruç kapsaminda Yahudilikteki Yom Kippur orucu ile İslam'daki Ramazan orucu birbirine teklif şekli bakımından benzemenin yanında her iki dinin dindarlarında bağışlanma ve arınma ümidi oluşturması bakımından da benzemektedir. Ancak Yahudilerin Yom Kippur orucu boyunca dünyevi iş yapmaları yasak iken Müslümanların Ramazan'da oruçlu iken çalışmaları yasak değildir. Sadece farziyet taşımamakla birlikte Ramazan'ın son on gününde gönüllü olarak girilen itikaf Yom Kippur'a biraz benzemektedir. Yom Kippur'un iki tam günlük oruç olmasına karşılık Ramazan'ın 30 gün süren oruç olması da ayrı bir farktır. Hıristiyanlıkta zorunlu oruca benzeyen genel oruçlarda dünya işleri terk edilmez. Ancak Hıristiyanlıkta oruç, yeme içmeyi tamamen bırakma şeklinde değil, kısmi perhiz şeklinde tutulması sebebiyle İslam'daki ve Yahudilikteki oruçtan ayrılmaktadır.

İlahi dinlerde karşılaştırılabilecek bir tür de kefaret oruçlarıdır. Üç ilahi dinde kefaret ile yapılan hatanın telafi edilmesi ve günahın bağışlanması amaçlanır. Bağışlanma yanında iradenin kontrol altına alınması ve nefis eğitimi gibi katkıları da söz konusudur. Yahudilik ve Hıristiyanlıktaki kefaret, ceza çekme, nefse eziyet verme, bedensel kuvveti zayıflatma, yas tutma gibi amaçlar taşırken İslam'daki kefaret böyle bir ceza ve zayıflama yerine insanın nefsini denetim altına alması ve iradesine hâkim olması anlamında psikolojik ve ahlaki gayeler gütmektedir. Burada iyimserlik ve Allah'a manen yakınlaşma amacı ön plandadır.

İlahi dinler, oruç ibadetindeki süreleri dakik olarak belirlemeyi önemsediklerinden bu gaye, bir zaman bilinci ve takvim oluşturma duyarlılı̆̆ sonucunu doğurmuştur. Bunun sonucu olarak program yapma, düzenli ve titiz olma gibi alışkanlıklar kazanılır. Paskalya bayramı öncesinde tutulan 40 gün oruç, İslam'daki bir aylık Ramazan orucu, haftalık tekrarlanan oruçlar, oruca şafağın sökmesi ile başlayıp gün bitimi ile tamamlama, planlı, programlı, zaman bilinci ile yaşama kültürünü kazandıran uygulamalardır. 
Sükût orucu, Yahudilikte önemli bir oruç türü olsa da İslam'da ve Hiristiyanlıkta kurumsallaşmamıştır. Ancak Kur'an, Hz. İsa'nın annesi Meryem'in sükût orucundan bahsetmektedir. Yahudilik peygamberlerinden Hz. Musa ve Hz. Zekeriya'nın da sükût orucu tuttukları bilinmektedir. Cahiliye âdetleri arasında yer alan sükût orucu İslam tarafından reddedilmiştir. Bu haliyle de olsa susma şeklinde icra edilen bu oruç, dil terbiyesi açısından önemlidir. İslam'da sükût orucu olmasa da itikaf büyük ölçüde inziva ve suskunlukla gerçekleştirilen bir nafile ibadettir. Hiristiyanlıkta sükût şeklinde kurumsallaşmış bir oruç olmasa da Hıristiyanlıkta oluşturulan manastır kültürü içinde inziva ve susma önemli bir yer işgal etmektedir. İslam'ın Kur'an ve Sünnete dayalı bir kurumu olmamakla birlikte tarihi süreçte teşekkül eden tasavvufi tekke kültüründe de bir çeşit inziva ve dolayısıyla suskunluk vardır. Yine de bu, Yahudilik ve Hıristiyanlıktaki sükût ile aynı şey değildir.

Aşura orucu, Yahudilik ile İslam'da mevcut iken, Hristiyanlıkta yoktur. Cahiliye döneminde de bilinen bu orucun İslam'a Yahudilikten geçtiği anlaşılmaktadır. Muharrem ayının 10'unda tutulan bu oruç, Ramazan orucunun farz kılınmasıyla isteğe bırakılmıştır. İslam ile Yahudilik ile arasında benzer olan bir diğer oruç Davud orucudur. Bu oruç İslam' da gün aşırı tutulmaktadır.

İlahi dinlerden her birine özgü hususi oruçlar vardır. Bilhassa Yahudilikte yaşanmış çeşitli acı olaylar ve felaketlerin anısına ihdas edilen hususi oruçlar vardır. Bu oruçlar, Yahudilerin tarihi bilinç oluşturarak milli ve dini kimliklerini muhafaza etme noktasında çok işlevseldir. Hıristiyanlıkta Hz. İsa'nın çarmıha gerilmesi anısına tutulan oruç, Ninova orucu da bu türdendir. İslam'da acı olaylara dayandırılan oruç anlayışı yoktur.

İlahi dinlerde sevindirici olaylara dayandırılan oruçlar da vardır. Yahudilikteki Ester orucu, izdivaç günü orucu, Hz. Musa' nın mucizevi kurtuluşunu temsil anısına tutulan oruç böyledir. Hıristiyanlıkta, Hz. İsa'nın doğumu ile ilgili Noel bayramı ve yeniden dirilişi ile ilgili Paskalya bayramları öncesinde tutulan oruçlar da bu türdendir. Ramazan orucunu Kur'an'ın indirilmeye başladığı ayda tutulan oruç olması hasebiyle değerlendirdiğimizde de aynı tür kapsamına dâhil etmemiz mümkündür. Ancak bu, Müslümanların değil, doğrudan şeriat koyucunun vaz ettiği bir oruçtur.

İlahi dinlerdeki orucu tutulduğu zaman dilimi ve oruç süresi bakımından da karşılaştırabiliriz. Her üç dinde de gerek Yom Kippur, gerek Noel ve Paskalya öncesi, gerek Ramazan ayı gibi yıl içinde eda edileceği belirli bir zaman dilimi bulunan oruçlar vardır. İslam'da bütün oruçlar sabah fecrin doğuşuyla başlar, akşam güneşin batmasıyla tamamlanır. Yahudilikte oruç süresi, sabah şafağın sökmesinden başlayıp akşam yıldızının doğmasına kadardır. Yahudilikte özel olarak iki gün daha doğrusu 25 saat süreyle kesintisiz tutulan Yom Kippur orucu vardır. Bu nevi şahsına münhasır bir oruçtur. Hıristiyanlıktaki oruçlar, Yahudilik ve İslam'dakinden farklı olarak günün çok kısa bir süresinde ve kısmi perhiz yapılarak tutulur. Sadece Ortodoks Süryaniler, Müslümanların orucuna benzer şekilde oruç tutmaktadırlar.

Yahudilikte Hahamların, Hıristiyanlıkta Kilisenin oruç emretme ve bozdurma yetkisi olduğu halde İslam'da bu şekilde yetkilendirilmiş hiçbir görevli yoktur. İslam'daki Ramazan orucu doğrudan Allah tarafından farz kılınmıştır. Nezir orucu ve bozulan nafile orucun kazası vacip kategorisinde olup bu, kişinin kendi üstlendiği görevi yapmak zorunda oluşu kapsamında değerlendirilmektedir. Nafile oruçlar ise ya Hz. Peygamber 
tuttuğu için ona uyma kabilinden ya da bireysel tercihle tutulan oruç kabilindendir. Bir din adaminın oruç ihdası söz konusu değildir.

Yahudilik ve İslam'da oruç günleri, Ay takvimi esas alınarak belirlenmektedir. Hristiyanlıkta oruç günleri ise Gregoryen yani Güneş takvimine göre belirlenmektedir. Kameri takvim, kişiye ömründe yılın her vaktinde oruç tutma imkânı sağlamaktadır. Güneş takviminde süre yıl içinde sabittir.

Oruç tutmak için sorumluluk çağı üç ilahi dinde farklı farklıdır. Yahudilikte on iki yaşını dolduranlar, Hristiyanlıkta yirmi bir yaşını dolduranlar, İslam'da ise akıllı olmak kaydıyla büluğ çağına girmiş olanlar oruç tutmakla yükümlüdür. İslam'a göre bir mazerete binaen Ramazan' da tutulamayan veya ister farz ister nafile oruç olsun bozulan oruçlar daha sonra günü gününe kaza edilir. Sadece Ramazan ayı orucunu mazeretsiz kasten bozanların 61 günlük kefaret orucu tutmaları gerekmektedir. Diğer iki dinde zamanında tutulamayan oruçların telafisi kişisel tercihe bırakılmıştır. Yaşlıların hangi yaştan itibaren oruçtan muaf olacağı konusunda Yahudilikte bir sinırlama yok iken Hıristiyanlıkta 60 yaş sinır1 getirilmiştir. İslam'da ise sınır olmamakla birlikte yaşlının beden sağlığının tutamayacak kadar kötüleşmiş olması esas alınır. Bu sadece yaşlılar değil, daha erken yaştaki hasta ve mazur kişiler için de geçerlidir. Ancak sağlıkları ileriye dönük de elvermediği için oruç tutamayanlar imkânları varsa fidye verirler, yoksa başka bir sorumlulukları yoktur.

\section{Sonuç}

Oruç, ilahi dinler yanında diğer dünya dinlerinde de bulunan bir ibadet şeklidir. Ancak biz bu makalede Yahudilik, Hıristiyanlık ve İslam dinlerinde orucu amaç, kaynak ve uygulanışı bakımından inceledik. Bu üç dinde oruçla ilgili benzer ve farklı birçok hususun olduğunu tespit ettik. Ancak orucun insanı kötülüklerden koruma ve Allah'a kulluk, teslimiyet arzı yönünün ortak olduğunu gördük. Özellikle Yahudilik ve Hıristiyanlıkta orucun tövbe ve kefaret yönü öne çıkmaktadır.

Yahudi Kutsal metinlerinde oruçla ilgili açık bir hüküm olmamakla birlikte nefislerin alçaltılması ifadesinden hareketle oruç tutma mecburiyeti çıkarılmaktadır. Yahudilikte cemaat halinde tutulan oruçlar olduğu gibi bireysel olarak tutulan oruçlar da vardır. Günahlara kefaret olması için sosyal felaketler dikkate alınarak oruç tutulur. Yahudi halkının bilinçli veya bilinçsizce yaptıkları kötü işlere kefaret ve pişmanlığın tezahürü olarak oruç tutulmaktadır. Yahudilikte oruç bir matem belirtisi olup Allah'a dua etmek için bir tür hazırlıktır.

Hz. İsa oruç hususunda yeni hüküm getirmemiş, Hz. Musa'nın şeriatına uymuştur. Başlangıçta kutsal kitapta belirgin bir hükmün olmayışı Hıristiyanların değişik dönemlerde oruçla ilgili sürekli yeni düzenlemeler yapmasına sebep olmuştur. Bununla birlikte İncil'de orucun nasıl tutulması gerektiğine dair güçlü vurgu ve uyarılar mevcuttur. Hıristiyanlıkta Çarşamba, cuma ve cumartesi günleri oruç tutmak için tercih edilen günlerdir. Ayrıca yılın belirli günlerinde perhiz uygulaması vardır. Fakat sonraki dönemlerde bazı oruç kuralları konmuştur. Hristiyanlıkta iki temel oruç Ökaristik ve Ekleziyastik oruçtur. Hıristiyanlıkta oruçlar mezheplere göre önemli farklılıklar göstermektedir. Hıristiyanlıktaki oruç İslam ve Yahudiliktekinden farklı olarak kısmi perhiz şeklinde uygulanmaktadır. 
Biz bu araştırma sonucunda üç ilahi dinin orucun kaynağı, amacı, uygulanışı ve şartları bakımından benzerlik ve farklılık gösterdiklerini tespit ettik. Özellikle orucun kişiyi günahlarından arındırma, ahlaki terbiye ve manen yücelmesini sağlama noktasında ortak amaçlar taşıdıkları görülmektedir. Ancak her üç dinde de şeriat koyucunun oruca dair birtakım açıklamaları olsa da İslam'da orucun belirli bir şekle bağlı olarak farz kılınması şeklinde bir farziyet diğer iki dinde bulunmamaktadır. Kur'an'daki “Oruç sizden öncekilere farz kılındığı gibi size de farz kılındı." Ayeti aslında Yahudilik ve Hıristiyanlıkta da orucun farz olduğuna işaret etmektedir. Bu iki dinin kutsal kitaplarında yer alan oruç konulu uyarılar orucun farz kılınmış olduğunu kanıtlamaktadır. Belki iki dinin kutsal kitaplarının otantik haliyle muhafaza edilememiş olması onlardaki emirleri indirildiği şekliyle görmemize engel olmaktadır.

Yahudilik ve Hıristiyanlıktaki oruç çeşitliliği İslam'da görülmez. Zira İslam'da farz olan bir tek bir aylık Ramazan orucu vardır. Vacip kategorisine giren oruçlar kişinin nezri veya başladığı nafileyi bozmasıyla doğan sorumluluktan ileri gelmektedir. Aşura orucu, Davud orucu, pazartesi ve Perşembe orucu, üç ayların girişinde tutulan oruç, Ramazanın çıkışında bayramdan sonra tutulan altı günlük Şevval orucu, Zilhicce orucu nafile kategorisinde yer almakta olup herhangi bir zorunluluk taşımaz.

Üç dindeki oruçların tutuldukları zaman dilimi ve oruçluluk süresi bakımından karşılaştırılması durumunda da bazı farklılıklarla karşılaşılmaktadır. İslam'da tutulan her oruç türü sabah fecrin doğuşuyla başlayıp akşam güneşin batmasıyla sona ermektedir. Yahudilik'te ya Yom Kippur' da olduğu gibi 25 saat süren uzun bir oruç ya da sabah gün doğuşundan akşam gün batımına kadar oruç şeklindedir. Hıristiyanlıkta ise bu süre daha kisadır.

\section{Kaynakça}

Ague, M. Paganizmin Dehası. çev. E. Atacay. Ankara: Dost Kitabevi Yayınları, 2010.

Ahmad, Abid. "Fasting in Religions". Subscription Review of Religions 97/3 (March 2002), 3342.

Alalu, S. - Klara, A. - Asayas, E. - Basmacı, T. - Ender, F. - Haleva, B. (vd.). Yahudilikte Kavram ve Değerler, Dinsel Bayramlar, Dinsel Kavramlar, Dinsel Gereçler. haz. Y. Altıntaş. İstanbul: Gözlem Gazetecilik Basın ve Yayın, 2001.

Arıklı, E. (ed.). Dinler Tarihi Ansiklopedisi. İstanbul: Gelişim Basım ve Yayım A.Ş., ty.

Aydın, Mehmet. "Hıristiyanlık". TDV İslam Ansiklopedisi. 17/340-345. Ankara: TDV Yayınları, 1998.

Besalel, Yusuf. Yahudilik Ansiklopedisi. İstanbul: Gözlem Gazetecilik Basın ve Yayın A.Ş, 2001.

Bickle, M. - Candler, D. The Rewards of Fasting, Frounner Books. Kansas City: 2005.

Bihlmeyer, K. - Tuchle, H. I. ve IV. Yüzyıllarda Hıristiyanlık. çev. A. Göral. İstanbul: Güler Matbaası, 1972.

Buhârî, Muhammed b. İsmail. el-Camiu's-Sahîh. İstanbul: Çağrı Yayınları, 1981.

Journal of Analytic Divinity, https://dergipark.org.tr/tr/pub/jad Volume 5/2 
Büyükkaya, Hasan. İlahi Dinlerde Oruç. Kastamonu: Kastamonu Üniversitesi Sosyal Bilimler Enstitüsü, Yüksek Lisans Tezi, 2018.

Calvin, J. The Institutes of the Christian Religion. trans. H. Beveridge. Grand Rapids: Public DomainRights, 2002.

Cilacı, Osman. İlahi Dinlerde Oruç, Hac ve Kurban. İzmir: Akyol Neşriyat ve Matbaacılık, 1980.

Demir, Recep. “Diğer İnanç Sistemlerinde ve İslam'da Oruç (Karşılaştırmalı Bir Analiz)”. Uluslararası Sosyal Araştırmalar Dergisi 9/42 (2016), 1785-1799.

Descuffi, Gluseppe. Hiristiyan Dini. İzmir: yy, 1963.

Dönmez, İ. Kafi. “İslam’da Oruç”. TDV İslam Ansiklopedisi. XXIII. İstanbul: TDV Yayınları, 2007.

Durak, N. Süryani Ortodoks Kilisesinde İbadet. İstanbul: Rağbet yayınları, 2011.

Ebu Davud, Süleyman b. El-Eş'as es-Sicistânî. es-Sünen. İstanbul: Çağrı Yayınları, 1981.

Erbaş, A. (2003). Hıristiyanlıkta İbadet. İstanbul: Ayışı̆̆ı Yayınları.

Eroğlu, Ahmet Hikmet. “Ekmek-Şarap Ayini (Eyharistiya) Konusunda Katolikler ve Protestanlar Arasındaki Anlayış Farklılıkları". Ankara Üniversitesi İlahiyat Fakültesi Dergisi, 39/1 (1999), 439-453.

Fasting and Fast Days. Jewish Virtual Library The Project of Aice. 2011. https:/ / www.jewishvirtuallibrary.org/fasting-and-fast-days-2, erişim. 10/05/2021

Feyizli, Hasan Tahsin. İslam'da ve Diğer İnanç Sistemlerinde Oruç-Kurban. İstanbul: Milli Eğitim Basımevi, 1993.

Güç, Ahmet. "Yahudilik'te Defin ve Sonrasına Ait Gelenekler". Uludağ Üniversitesi İlâhiyat Fakültesi Dergisi 10/1 (2001), 63-78.

Gündüz, Şinasi. Din ve İnanç Sözlüğü. Ankara: Vadi Yayınları, 1998.

Herr, Mosha David. "Fasting and Fast Days". Encyclopedia Judaica Second Edition. ed. F. Skolnik. Detroit: Thomson - Gale, 2007.

Hughes, A. Medival Manuscripts for Mass and Office. Toronto: A Guide to Their Organization and Terminology, 1995.

Karesh, S. E. - Hurvitz, M. M. Encyclopedia of Judaism. New York: Facts on File Inc., 2005.

Katar, Mehmet. “Dinlerde Kefaret Anlayışı”. Dini Araştırmalar Dergisi 1/1 (1998), 44-58.

Kutsal Kitap (Tevrat, Zebur, İncil) -Yeni Çeviri-. Korean Bible Society: Yeni Yaşam Yayınları, 2011.

Küçük, Abdurrahman - Tümer, Günay - Küçük M. A. Dinler Tarihi. Ankara: Berikan Yayinevi, 2010. 
Levin, Michael. Yahudi Ruhaniliği ve Mistisizmi. çev. E. Seval Vali. İstanbul: Gözlem Gazetecilik Basın ve Yayın A.Ş, 2006.

Milgrom, J. "Fasting and Fast Days". Encyclopedia Judaica Second Edition. ed. in Chief, F. Skolnik. vol. VI. Detroit: Thomson - Gale, 2007.

Milgrom, Jacob. "Forgiveness, in the Bible". Encyclopaedia Judaica Second Edition, ed. in Chief, F. Skolnik. Vol. VII. Detroit: Thomson - Gale, 2007.

Müslim, Ebu'1-Huseyn b. El-Haccac. Sahihu Muslim. İstanbul: Çağrı Yayınları, 1981.

Olgun, Tahir. Müslümanlıkta İbadet Tarihi. Ankara: Akçağ Yayınları, 1998.

Özen, Adem. Yahudilikte İbadet. İstanbul: Ayışı̆̆1 Yayınevi, 2001.

Soysaldı, Mehmet. Kur'an ve Sünnet Işı̆̆ında İbadet Tarihi. Elazı̆̆: TDV Yayınları, 1998.

Sulliven, J. F. The Externals of the Catholic Church. Rev. J. C. O'Leary. New York: Kenedy, 1951.

Şentürk, Lütfi -Yazıcı, Seyfettin. İslâm İlmihali. Ankara: Diyanet İşleri Başkanlığı Yayınları, 2004.

Tirmizî, Ebu İsa Muhammed b. İsa. Sahihu't-Tirmizî. İstanbul: Çă̆rı yayınları, 1981.

Uysal, Veysel. Psiko-Sosyal Açıdan Oruç. Ankara: TDV Yayınları, 1994.

Ünal, Asife. "Yahudi Düğün Gelenekleri”. İnsan ve Toplum Bilimleri Araştırmaları Dergisi 5/2 (2016), 225-261.

Yitik, Ali İhsan. "İzmirli İsmail Hakkı ve Diğer Dinlerde Oruç". İzmirli İsmail Hakkı Sempozyumu 24-25 Kasım. 1995. 215-237. Ankara: TDV Yayınları, 1995.

Yitik, Ali İhsan. “Oruç”. TDV İslam Ansiklopedisi. 28/414. İstanbul: TDV Yayınları, 2007. 